\title{
How Much Do Emotional, Behavioral, and Cognitive Factors Actually Impact College Student Attitudes towards English Language Learning? A Quantitative and Qualitative Study
}

\author{
Xin Zuo ${ }^{1}$, Regina Weaver ${ }^{2}$, Julia MacRae ${ }^{2}$ and Limin Wang ${ }^{3, *}$ \\ 1 School of Foreign Languages, Changchun University of Technology, Changchun 130012, China; \\ valeriazuo@126.com \\ 2 Intensive English Language Program, Portland State University, Portland, OR 97201, USA; \\ dbrw@pdx.edu (R.W.); youst@pdx.edu (J.M.) \\ 3 College of Computer Science and Technology, Jilin University, Changchun 130012, China \\ * Correspondence: wanglim@jlu.edu.cn
}

Received: 13 March 2019; Accepted: 15 April 2019; Published: 5 May 2019

\begin{abstract}
Researchers have proposed many multidimensional frameworks to identify significant and potential factors, e.g., educational background, positive feelings and career aspirations, that impact English learning attitude in second language acquisition. Yet, there is still very little research to graphically describe the interactions between these factors and how these factors directly or indirectly impact learning attitude. To this end, a questionnaire survey was conducted in Changchun University of Technology. Statistical measures and Bayesian network analysis were introduced to quantitatively and qualitatively analyze the collected data. Furthermore, the significant attitudinal differences between students majoring in the Liberal Arts or Sciences were investigated for the case study. Studying the interaction between these factors can help explain how they positively affect students' attitudes toward English language learning. To stimulate interest, teachers may take targeted pedagogical approaches or strategies.
\end{abstract}

Keywords: quantitative and qualitative study; Bayesian network; interactions between deciding factors; English learning attitude

\section{Introduction}

In China, most primary school students begin to learn English as a foreign language (EFL) in the first grade. English is a compulsory course for Chinese undergraduate students. However, the online survey report on English education in China [1], which was conducted by the 21st Century Education Research Institute in Beijing, showed that children who were interested in English accounted for only $10.62 \%$ of the total. Besides an intellectual interest in language skills, achievement in a target language depends primarily on psychological factors. In the case of many people, the learner' attitudes towards the target language (L2) and the target community (L2 speakers), such as feelings, beliefs, likes, dislikes, needs, are viewed as psychological construct and impact on L2 learner success in L2 acquisition [2-4].

A large number of studies on language attitudes have been conducted over the past 50 years because of the growing relation between the importance of language use and the nature of individuals, such as students' attitude toward different teaching strategies [5-12], students' attitude towards reading [13,14], writing [15] and Utilization of iPad [16], relationship between attitudes and motivation $[17,18]$. In his great work "Principles of Language Learning and Teaching", Brown (1994) [19] stated that "attitudes are the result of parents' and peers' attitudes, contact with people 
who are different in any number of ways, and interacting affective factors in the human experience". It seems obvious that, in many cases, there are many factors, including social and psychological factors, educational background, positive feelings and career aspirations, that lead to a positive or negative attitude towards the target language. Pienemann and Johnston (1987) [20] came up with a distinction between factors which are "external" and "internal" to the learner. External factors are variables ranging from social environment, and biological factors such as age. Internal factors are described as aspects of the learner's cognitive and linguistic capacities and the mental structures which determine these capacities. Spolsky (1989) [21] refers to four groups of factors (Kp, A, M, O) as necessary conditions for any effective second language learning. " $\mathrm{A}$ " factors represent various components of ability including physiological, biological, intellectual and cognitive skills, " $\mathrm{Kp}$ " factors represent existing knowledge of the learner, " $\mathrm{M}$ " factors represent affective factors including attitudes and motivation, and " $\mathrm{O}$ " factors represent opportunity for learning the language. Eshghinejad (2016) [22] stated that attitude concept can be viewed from three dimensions regarding aspects of it, i.e., behavioral, cognitive, and emotional. Each one of these dimensions has different features to bring out language attitude results. The behavioral factors deal with the way one behaves and reacts in particular situations. Cognitive factors involve the beliefs of the learners about the knowledge that they receive and their understanding of the learning process. Emotional factors help teacher and students engage in various emotional activities.

Over the past years, statistical analysis on language attitude has been widely employed from different perspectives and with various dimensions. In terms of behavioral aspect of attitude, Kara (2009) [23] processed the data obtained from 150 participants with SPSS, conducted samples t-tests, independents samples t-tests and correlation tests. The results suggested that positive attitude leads to the exhibition of positive behavior toward studying. Cognitive aspect of attitude responds to the learners' beliefs in knowledge and understanding during language learning. Eshghinejad (2016) [22] randomly selected 30 male and female freshman EFL students in the State University of Kashan and asked them to answer to the questionnaires. A t-test was applied to analyze the possible significance of the observed differences between male and female learners. Most of the respondents said that they enjoy learning English, not just for passing their exams. All respondents agreed that more knowledge and understanding are possible with learning English. With respect to the emotional aspect of attitude, Yasuhiro (2010) [24] collected the data taken from the fifth meeting of one group consisting of three female students for case study. He stated that "emotions do not merely facilitate, filter, or hinder an individual's inner cognitive functioning; rather, they can in any forms mediate development".

With the rapid development of data mining, many people hope to acquire knowledge (besides statistical data) from mathematical models in terms of inference considerations, complexity considerations and visualization. These models can help extract information from data and transform the information into a comprehensible structure for further analysis. Regression analysis provides a statistical tool for evaluating the relationships among variables. Most commonly, regression analysis estimates the conditional expectation of the dependent variable given the independent variables, that is, the average value of the dependent variable when the independent variables are fixed. $\mathrm{Yu}$ (2014) [25] proposed to build multiple linear regression model with the influencing factors of English reading ability based on the sample data. Katalin et al. (2016) [26] used linear regression model to identify explanatory variables (educational funding rates and the number of students learning English language) which influence and mostly determine the quality of public education. However, regression analysis can deal with continuous variables rather than discrete variables. Bayesian Networks (BNs) are popular graphical model for encoding probabilistic relationships among a set of variables. They have been shown to be remarkably effective for data-modeling problems in different research domains, including medicine $[27,28]$, business [29,30] and education [31,32], etc. This study contributes to an understanding of English learning and teaching and adds to the growing body of studies on the spread of English. The study is led by the following research questions: 
(1) Is there a significant difference among the students' attitudes towards English learning in terms of major?

(2) Which factors may have positive/negative impact on students' attitudes and how do these factors directly or indirectly work?

The primary aim of the qualitative and quantitative study lies in its attempt to identify the interaction between different factors which might be associated with the English learning attitude of second language students. This study should be of interest to a number of researchers focusing on English as a foreign language for learners, English education policies and curriculum makers. By providing insights into attitudes of English learners and their purposes for learning English, this study can help teachers understand why their attitudes toward learning English vary so greatly and take a targeted pedagogical approach. In this paper, we collect some base data of deciding factors through questionnaires, calculate statistical data such as mean value and mutual information, and then apply one of the state-of-the-art BNs, which is the so-called tree augmented naive Bayes (TAN) [33], to describe the interactions among these factors. After that, we report the main findings, which reveal the existing problems of EFL students in China, and we advocate for feasible pedagogical strategies to improve students' attitudes and enhance their learning aspiration. Finally, we briefly discuss the value and significance of quantitative and qualitative analysis for English learning.

\section{Material and Methods}

\subsection{Design}

One attitude questionnaire, shown in Table 1, was the only instrument used to collect the data. The questionnaire was adopted from the Attitude Questionnaire employed by Eshghinejad (2016) [22]. This paper analyzes English learning attitudes from a multiple interdisciplinary perspective by taking into consideration background characteristic factors (that are gained by an organism after birth, e.g., age or gender), behavioral factors (that deal with the way one behaves and reacts in particular situations, e.g., personality or interpersonal relationship), cognitive factors (that involve the beliefs of the learners about the knowledge that they receive and their understanding of the learning process), emotional factors (that help people engage in emotional activities, e.g., enjoyment and importance) and future expectation factors (that are related to future plan, e.g., higher education) as attributes for BN analysis.

The questionnaire consisted of 12 items (from Q1 to Q12) and 1 self-evaluation attitude towards English language learning. The first three items, from Q1 to Q3, are about the students' background characteristics, including grade, gender and major. Items Q4-Q5, Q6-Q8 and Q9-Q10 obtain participants' feelings in terms of behavioral, cognitive and emotional aspects toward English language learning. Items Q11 and Q12 elicit participants' feelings in terms of future expectation including career aspirations and education aspirations. The questionnaire divided attitudes into three groups: positive, negative and neutral. 
Table 1. Detail of the questionnaire.

\begin{tabular}{|c|c|c|c|}
\hline No & Items & Possible Answers & Symbol \\
\hline Q1 & Grade & $\{1,2,3,4\}$ & $X_{1}$ \\
\hline $\mathrm{Q} 2$ & Gender & $\{$ Male, Female\} & $X_{2}$ \\
\hline Q3 & Major & $\{$ Liberal Arts, Science $\}$ & $X_{3}$ \\
\hline Q4 & $\begin{array}{l}\text { Studying English helps improve my } \\
\text { personality, or personality for short }\end{array}$ & $\{1,2,3\}$ & $X_{4}$ \\
\hline Q5 & $\begin{array}{l}\text { Studying English helps maintain good } \\
\text { interpersonal relationship, or relationship } \\
\text { for short }\end{array}$ & $\{1,2,3\}$ & $X_{5}$ \\
\hline Q6 & $\begin{array}{l}\text { Studying English helps gain knowledge } \\
\text { and understand cultural differences, or } \\
\text { knowledge for short }\end{array}$ & $\{1,2,3\}$ & $X_{6}$ \\
\hline Q7 & $\begin{array}{l}\text { Studying English helps create new } \\
\text { thoughts, or thoughts for short }\end{array}$ & $\{1,2,3\}$ & $X_{7}$ \\
\hline Q8 & $\begin{array}{l}\text { Frankly, I study English just to pass the } \\
\text { exams, or exams for short }\end{array}$ & $\{1,2,3\}$ & $X_{8}$ \\
\hline Q9 & $\begin{array}{l}\text { Studying English is enjoyable, or } \\
\text { enjoyment for short }\end{array}$ & $\{1,2,3\}$ & $X_{9}$ \\
\hline Q10 & $\begin{array}{l}\text { English is important in my life, or } \\
\text { importance for short }\end{array}$ & $\{1,2,3\}$ & $X_{10}$ \\
\hline Q11 & $\begin{array}{l}\text { I plan to work for transnational or foreign } \\
\text { corporations, or corporations for short }\end{array}$ & $\{1,2,3\}$ & $X_{11}$ \\
\hline \multirow[t]{2}{*}{ Q12 } & $\begin{array}{l}\text { I plan to apply for Master or PhD degree, or } \\
\text { degree for short }\end{array}$ & $\{1,2,3\}$ & $X_{12}$ \\
\hline & Attitude & $\begin{array}{l}\text { \{Negative or N, Neutral } \\
\text { or O, Positive or P\} }\end{array}$ & Y \\
\hline
\end{tabular}

\subsection{Procedure for Data Collection}

In September 2017, 136 questionnaires were sent to undergraduate EFL students from different colleges in the library of Changchun University of Technology to assess their English learning attitudes. The questionnaire didn't contain any privacy-sensitive personal information, such as name, phone number or address. For ethical considerations, the purpose and details of the experiment were explained to the participants by oral explanation and each participant gave informed oral consent. All the items in the questionnaire were required to be answered and returned in twenty minutes. Among the collected questionnaires, ten were invalid because of missing answers and the valid return rate was $92.6 \%$. The results of the questionnaires for students majoring in the Liberal Arts (L-student) and students majoring in Science (S-student), which are, respectively, shown in Tables A1 and A2 (see Appendix A), were used for the main study. Then, the items were processed by using SPSS software to estimate the average value, the probability and conditional probability distributions of these factors. Finally, we computed the conditional mutual information for each factor pair and build TAN for further analysis. More specially, the mutual information between different factor and attitude was applied to analyze the possible significance of the observed differences between students majoring in Liberal art and those in Science in terms of emotional, behavioral, and cognitive aspects.

\subsection{Demographical Information of the Participants}

In this study, the sampling procedure made effort to achieve roughly equal proportions of questionnaires from each type of major (Liberal Arts or Science). Among all the participant who gave the valid questionnaires, 64 were L-students and 62 were S-students. In terms of gender, 80 were female and 46 were male. About $35.7 \%$ of students showed positive attitude and $31.7 \%$ of students showed negative attitude towards English learning. Their ages ranged between 18 and 20 with an average of 19. Among them, $21(16.7 \%)$ students were freshman, $41(32.5 \%)$ students were sophomore, $41(32.5 \%)$ students were junior, 23 (18.3\%) students were senior (see Figure 1). 


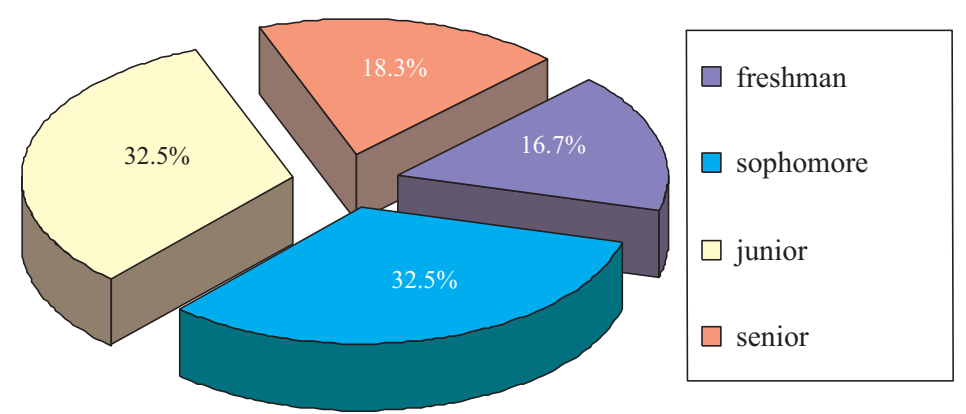

Figure 1. Grade distribution of students.

\subsection{Statistical Method}

Bayesian networks (BNs) are powerful tools for reasoning under conditions of uncertainty [33,34]. A BN, $\mathcal{B}$, consists of two parts, which can be described as $\mathcal{B}=\langle\mathcal{G}, \Theta\rangle$. The network structure $\mathcal{G}$ is a directed acyclic graph (DAG). Nodes in $\mathcal{G}$ represent the attributes $X_{i}(1 \leq i \leq n)$ or class variable $Y$, and arcs denote the probability dependencies between different nodes. (In the following discussion, capital letters ( for example, $X_{i}$ ) is used to represent attribute names and the corresponding lowercase letters (for example, $x_{i}$ ) represents the values taken by those attributes.) Parameter $\Theta$ quantitatively describes the conditional dependencies and contains the conditional probability distribution for each node.

By applying Kruskal's algorithm [35], the basic structure of TAN is a maximum weighted spanning tree with $n-1$ arcs, where the weight of an arc $X_{i}-X_{j}$ is measured by conditional mutual information $I\left(X_{i} ; X_{j} \mid Y\right)$ as follows [36],

$$
I\left(X_{i} ; X_{j} \mid Y\right)=\sum_{x_{i}} \sum_{x_{j}} \sum_{y} P\left(x_{i}, x_{j}, y\right) \log \frac{P\left(x_{i}, x_{j} \mid y\right)}{P\left(x_{i} \mid y\right) P\left(x_{j} \mid y\right)}
$$

In TAN, each attribute $X_{i}$ is supposed to be directly related to class variable $Y$. In this paper, the weight of an arc $X_{i}-Y$ is measured by mutual information $I\left(X_{i} ; Y\right)$ as follows [36],

$$
I\left(X_{i} ; Y\right)=\sum_{x_{i}} \sum_{y} P\left(x_{i}, y\right) \log \frac{P\left(x_{i}, y\right)}{P\left(x_{i}\right) P(y)}
$$

The procedure of building TAN is depicted in Algorithm 1 below.

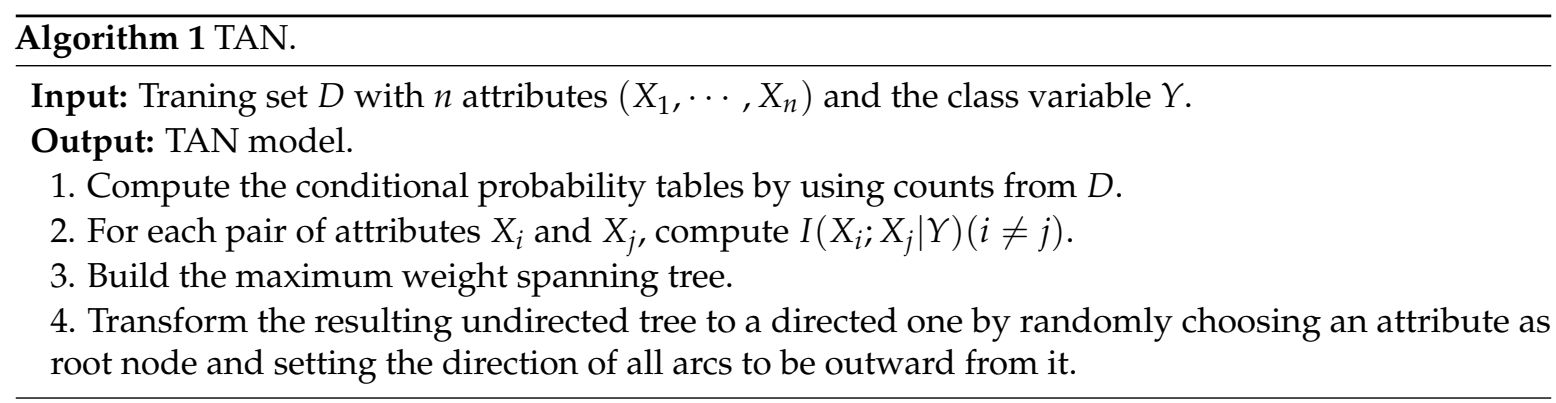

In the following study, each questionnaire corresponds to a training instance, question items in questionnaire correspond to the nodes, and the learning attitude corresponds to the class variable in TAN, respectively.

\section{Results}

By collecting data through questionnaires, these quantitative measures, e.g., mutual information and conditional mutual information, can measure the extent to which factors independently or jointly impact attitude toward English language learning for EFL students. By using BN to analyze the 
relationship between the different factors or items, the network structure can qualitatively clarify how these factors interact, and then help teachers develop target strategies to enhance students' learning aspirations. The integration of qualitative and quantitative analysis can help acquire a multi-dimension picture of students' cognition, behavior and emotion relevant to learning attitude.

The quest to identify significant and potential factors leading to success or failure in learning a language has been an important part of research in second language acquisition [37,38]. Because there are many potential factors, in this paper we come up with a distinction between factors which are "external" and "internal" to the learner. External factors include educational background and biological characteristic, such as grade, major and gender. Internal factors are described in terms of the learner's feelings or conceptions, such as behavioral factors, cognitive factors, emotional factors and future expectation factors.

Statistical data of all the items were collected to examine which factors affected the attitude of EFL students and how these factors interacted. Statistical correlation analyses can be performed by using TAN to identify the internal dependency relationships between the perceived factors in learning English for EFL students. In TAN, nodes $\left\{X_{1}, \cdots, X_{12}\right\}$ correspond to items $\{Q 1, \cdots, Q 12\}$ in Table 1 , $Y$ corresponds to English learning attitude and $\operatorname{arc} X_{i}-X_{j}$ represents the interaction between $X_{i}$ and $X_{j}$. Mutual information (MI) $I\left(X_{i} ; Y\right)$ was applied to measure the impact of deciding factor $X_{i}$ on attitude $Y$. Conditional mutual information (CMI) $I\left(X_{i} ; X_{j} \mid Y\right)$ was applied to measure the weight of interaction between factors $X_{i}$ and $X_{j}$. Because of the symmetry of definition of CMI, the directed $\operatorname{arcs} X_{i} \rightarrow X_{j}$ and $X_{j} \leftarrow X_{i}$ in TAN denoted the same interaction between $X_{i}$ and $X_{j}$. The MI and CMI values of internal factors (such as behavioral factors, cognitive factors, or emotional factors) were applied for quantitative analysis. The topology of TAN corresponding to CMI matrix was applied for qualitative analysis.

\subsection{Statistical Analysis for All Students and Discussion}

First of all, we analyzed 126 questionnaires and provided an overall analysis of the deciding factors on the EFL students' attitude toward English language learning. The details of MI and mean values of each deciding factor are shown in Figure 2, which reflect how all the factors independently impact students' attitudes. The higher the value of MI is, the more strongly corresponding factors impact the English learning attitude of the sample students. Because the mean values of external factors, e.g., gender, are meaningless, they are not included in Figure 2.

By comparing the statistical results of MI from Figure 2 we can see that, among all the external factors, $X_{1}$ (Grade) achieved the highest MI value and thus it was more relevant to attitude than the other two factors. This phenomenon may be explained by the fact that a general English course in Chinese universities is compulsory only for freshman and sophomore. Juniors and seniors may focus on other courses to facilitate the development of their other abilities for future work or study. For example, the freshman majoring in computer science must take ten compulsory courses whereas no compulsory courses are required for seniors. Thus seniors have more free time to choose any courses they like. Among all of the internal factors, $X_{10}$ (importance) achieved the highest MI value (0.2806) and mean value (2.0635). Over $31.1 \%$ of the participants recognized the importance of English. The majority of them (over 67.8\%) showed positive attitude to English language learning. Thus, emotional factor played an important role in eliciting the positive attitude toward English language learning. On the other hand, the first and the most important function of language is communication. Students need to be aware of the various social contexts and the appropriate language to use in various social situations. This helps to round out their English language knowledge. However, based on the low MI and mean values of $X_{5}$ (relationship), self-directed learning needs to improve. Among all the internal factors $X_{8}$ (exams) achieved the second highest mean value (1.9048) only after $X_{10}$ (importance) (2.0635). That means many students learned English not for its importance and knowledge, but mainly for passing exams. $50.8 \%$ of the participants disagreed and only $11.1 \%$ agreed that studying English was interesting and made them feel good. This can help clarify students' ambivalence about reluctant 
English learning in the present compulsory English education system. English is very important for people who attend international conferences, write academic papers, and communicate with English native speakers. However, since undergraduate students have less chance to participate in these activities, their learning motives are weak. Although they do understand the importance of learning English, their learning motives are not strong enough. The MI value of $X_{12}$ (degree) is much higher than that of $X_{11}$ (corporations). That means education aspiration plays a more important role than career aspiration. The main reason may be that students must pass the entrance examination of English to apply for a Masters or $\mathrm{PhD}$ degree. In preparation for exams, students make substantial and continuous effort on vocabulary, collocation, pragmatics, semantics, syntax and phonology, all of which will help them achieve a high score on an entrance exam; these students show a more positive attitude toward English language learning. In contrast, although students put considerable effort into preparing for an interview, the chance of working in transnational or foreign corporations is very small. To some extent, this may diminish their interest in English language learning.

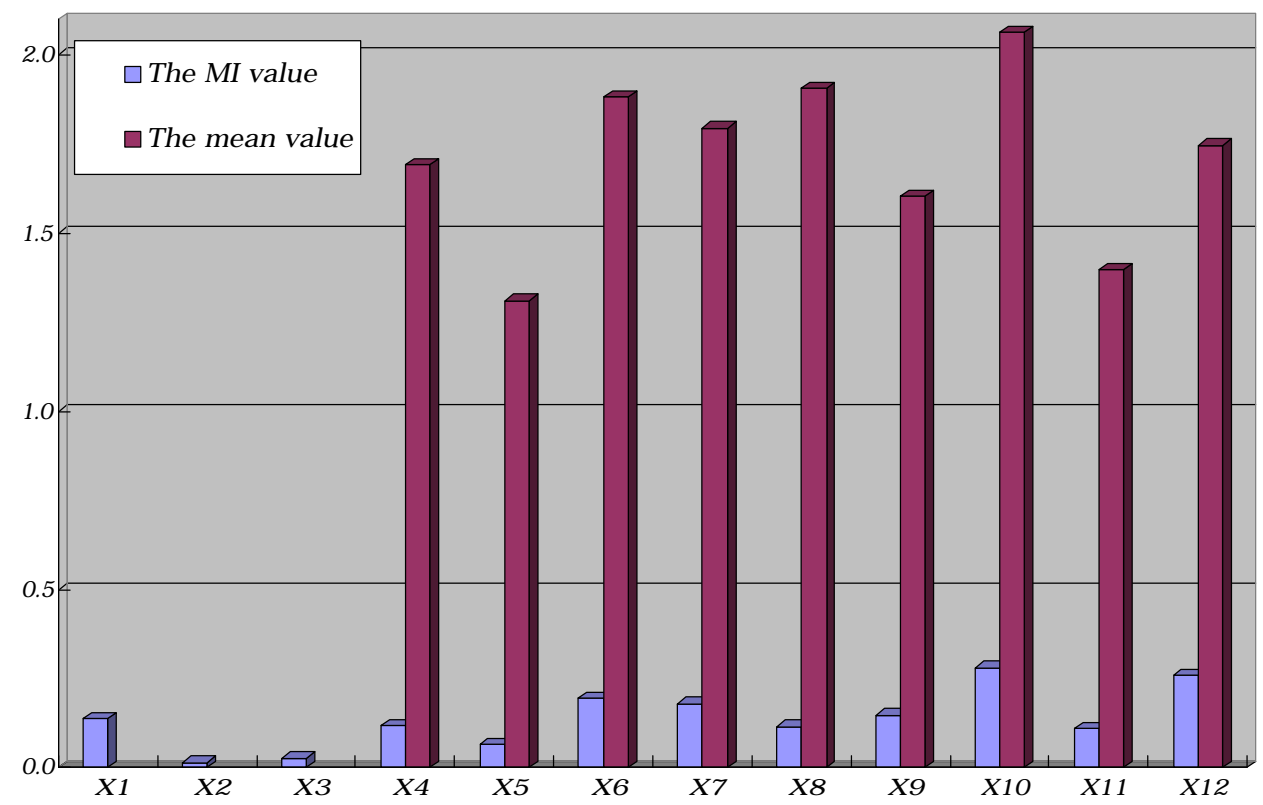

Figure 2. The MI and mean values of each deciding factor for all students.

The lower triangular matrix of CMI for deciding factors to English learning attitude is shown in Table 2, in which cell $[i ; j]$ contains the value of CMI between the item on row $i$ and the item on column $j$. The topology of TAN is shown in Figure 3. The CMIs that correspond to the significant arcs or interactions in Figure 3 are highlighted in Table 2.

Since these factors interact with each other and may impact indirectly learning attitude, the interaction will provide further information for analysis. In Figure 3, $\operatorname{arcs} X_{6}$ (knowledge)- $X_{7}$ (thought), $X_{9}$ (enjoyment)- $X_{10}$ (importance), and $X_{12}$ (degree)- $X_{11}$ (corporations) demonstrate that the cognitive factors are closely related with each other, and so do emotional factors and future expectation factors. Arcs $X_{4}$ (personality)- $X_{9}$ (enjoyment)- $X_{5}$ (relationship) show that, behavioral factors, e.g., $X_{4}$ (personality) and $X_{5}$ (relationship), are also indirectly related via $X_{9}$ (enjoyment), and emotional factor $X_{9}$ (enjoyment) affected $X_{4}$ (personality) and $X_{5}$ (relationship) greatly. From Table 3, the mean value of $X_{9}$ (enjoyment) is only 1.6032, relatively low. Thus, it shows students' unpleasant feelings toward English language learning. Moreover, arcs $X_{9}$ (enjoyment)- $X_{4}$ (personality) and $X_{9}$ (enjoyment)- $X_{5}$ (relationship) demonstrate that the unpleasant feeling of learning English made students feel depressed in developing personality and interpersonal relationships. The arc $X_{8}$ (exams)- $X_{9}$ (enjoyment) indicates that the experience in the English classroom affects the learning bias. The mean value of $X_{8}$ (exams) 
is the second highest after $X_{10}$ (importance). For students with unpleasant feelings toward English language learning, the students with the aim of passing exam are over double the students without it. Note that in Figure 3, $X_{9}$ (enjoyment) is closely related to the largest number of factors. The result suggests that, although $X_{9}$ (enjoyment) does not have a deciding impact on the attitude toward English language learning, it directly or indirectly affects most factors. How to make the learning procedure interesting and enjoyable is the key issue. To further analyze whether these factors interact differently for students in different majors, in the following discussion we divided the data into two groups in terms of major.

Table 2. The CMI matrix of deciding factors to attitude toward English language learning.

\begin{tabular}{|c|c|c|c|c|c|c|c|c|c|c|c|c|}
\hline$I\left(X_{i} ; X_{j} \mid Y\right)$ & $X_{1}$ & $X_{2}$ & $X_{3}$ & $X_{4}$ & $X_{5}$ & $X_{6}$ & $X_{7}$ & $X_{8}$ & $X_{9}$ & $X_{10}$ & $X_{11}$ & $X_{12}$ \\
\hline$X_{1}$ & 0.0000 & & & & & & & & & & & \\
\hline$X_{2}$ & 0.0976 & 0.0000 & & & & & & & & & & \\
\hline$X_{3}$ & 0.2504 & 0.0088 & 0.0000 & & & & & & & & & \\
\hline$X_{4}$ & 0.1993 & 0.0413 & 0.0785 & 0.0000 & & & & & & & & \\
\hline$X_{5}$ & 0.1008 & 0.0364 & 0.0164 & 0.1282 & 0.0000 & & & & & & & \\
\hline$X_{6}$ & 0.1535 & 0.0907 & 0.0434 & 0.2486 & 0.1161 & 0.0000 & & & & & & \\
\hline$X_{7}$ & 0.1670 & 0.0682 & 0.0525 & 0.1640 & 0.1509 & 0.6861 & 0.0000 & & & & & \\
\hline$X_{8}$ & 0.1208 & 0.0162 & 0.1489 & 0.2373 & 0.1192 & 0.2305 & 0.2326 & 0.0000 & & & & \\
\hline$X_{9}$ & 0.2533 & 0.0351 & 0.1625 & 0.2866 & 0.2426 & 0.2476 & 0.2339 & 0.2905 & 0.0000 & & & \\
\hline$X_{10}$ & 0.1554 & 0.0390 & 0.1567 & 0.1842 & 0.1994 & 0.3770 & 0.3118 & 0.2358 & 0.2930 & 0.0000 & & \\
\hline$X_{11}$ & 0.1600 & 0.0294 & 0.1780 & 0.0809 & 0.0255 & 0.0404 & 0.0534 & 0.1190 & 0.1103 & 0.0726 & 0.0000 & \\
\hline$X_{12}$ & 0.1772 & 0.0123 & 0.3317 & 0.1529 & 0.0670 & 0.1134 & 0.1987 & 0.1054 & 0.2468 & 0.1852 & 0.4963 & 0.0000 \\
\hline
\end{tabular}

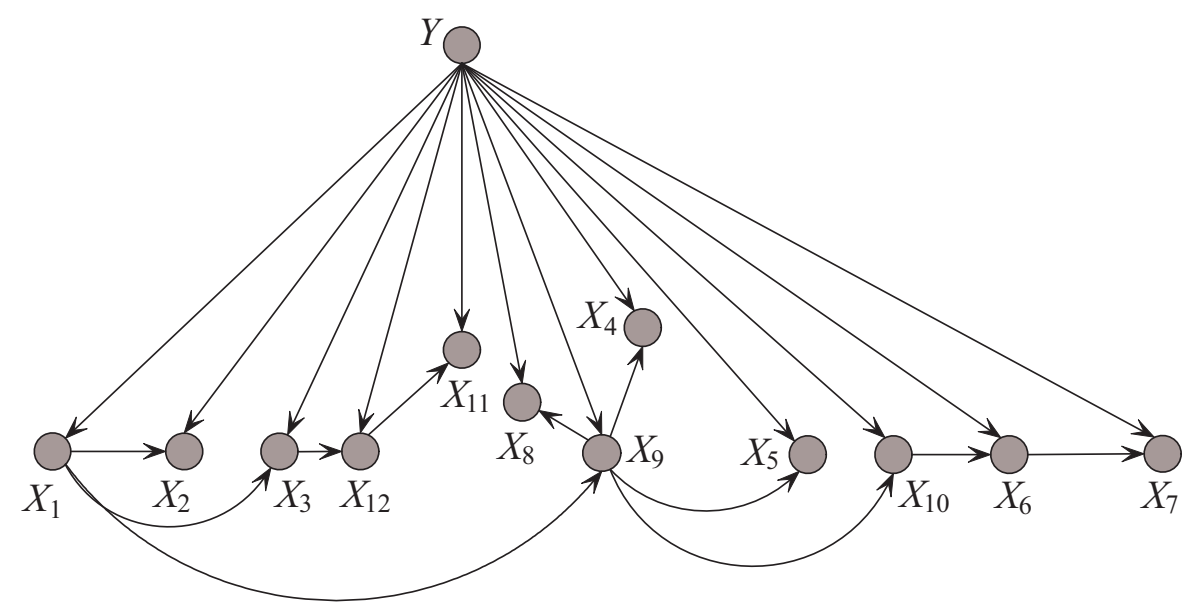

Figure 3. The topology of TAN corresponding to the CMI matrix shown in Table 2.

\subsection{Statistical Analysis for L-Students and Discussion}

By comparing the statistical results of $\mathrm{MI}$ in Figure $4, X_{1}$ (Grade) still achieved the highest MI value among the external factors. Among all internal factors, $X_{6}$ (knowledge) and $X_{7}$ (thoughts) achieved relatively high MI values and mean values, thus these two factors were more important with regards to attitude. L-students opted to improving their knowledge acquisition. $28.1 \%$ of them agreed and 9.5\% disagreed to having knowledge and understanding when studying English. 29.7\% of them agreed and $6.3 \%$ of them disagreed that studying English helped create new thoughts. It seemed that English language learning broadened the L-students' horizons with diversity, specialized knowledge, and new insights; it seemed to be an incentive to create new ideas. In China, many university libraries cannot offer various contemporary English books due to their limited funds. For undergraduate students, following their English content interests is difficult when there are only old books to be borrowed from the library. With the development of the Internet and the wide use of information technology in teaching, college teachers may recommend more listening and reading materials, such as online English newspapers or programs. 


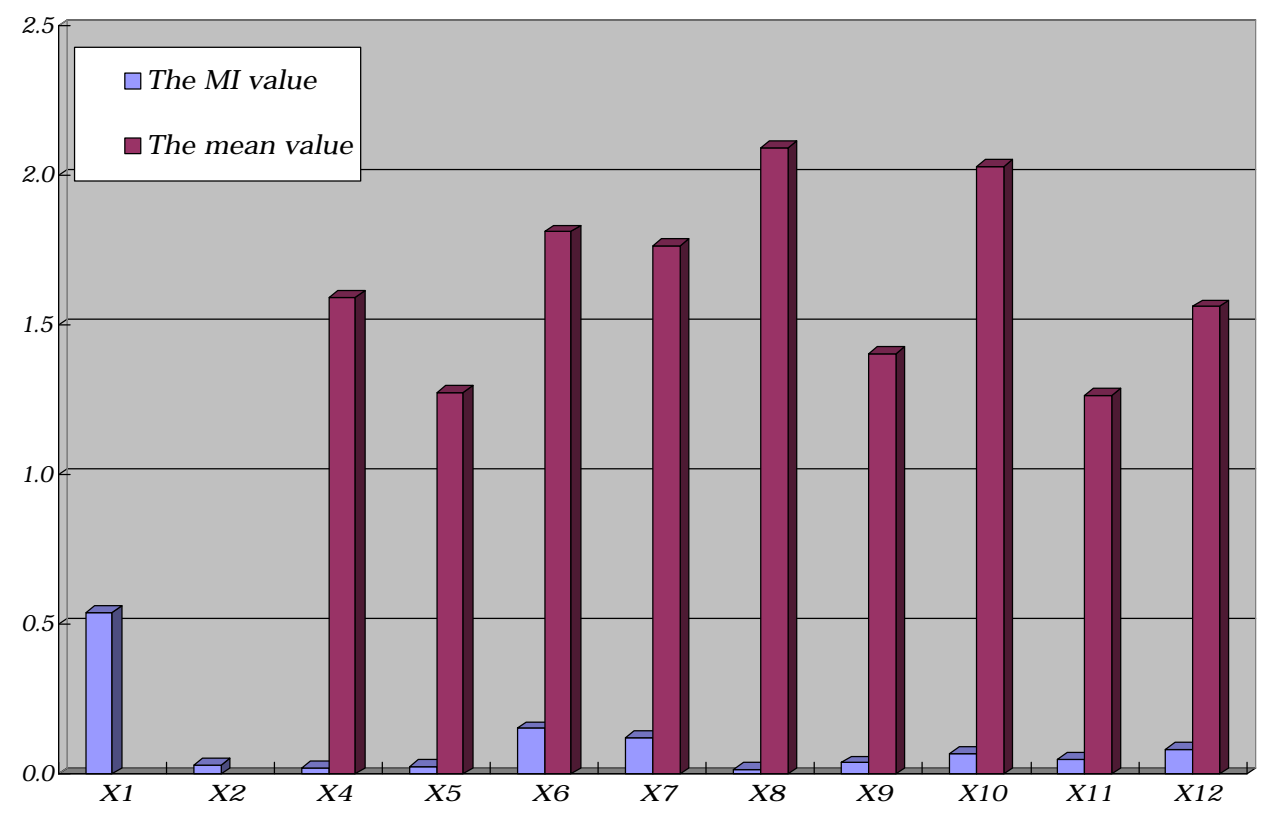

Figure 4. The MI and mean values of each deciding factor for L-students.

In contrast, $X_{4}$ (personality) and $X_{5}$ (relationship) achieved relatively small MI values and mean values, indicating that behavioral factors are less important toward attitude; moreover, learning English does not help improve their personality or interpersonal skills. In China, the exam result is the only performance evaluation criterion for students. Thus students often focus on language points, which are focal points for the final exam, while ignoring the information or ideas conveyed by articles. For example, the reading comprehension part of Band Four in the College English Test requires that, from a list of choices the students choose the words that best fit the blanks in the given passage. The unpleasant learning experience causes students to lose the interest and enthusiasm in acquiring the target language to communicate with others, and it leads them to focus mostly on the grammatical components of English.

The CMI matrix for L-students is shown in Table 3 and the corresponding topology of TAN is shown in Figure 5. In Figure 5, the $\operatorname{arc} X_{7}$ (thought)- $X_{6}$ (knowledge)- $X_{4}$ (personality) demonstrates that $X_{6}$ directly and $X_{7}$ (thought) indirectly impacted $X_{4}$ (personality). Thus it is $X_{6}$ (knowledge) and $X_{7}$ (thought) that can help improve students' personality. Classics, famous biographies, or spoken English should be implemented instead of grammar books as a means of improving students' personality during English language learning. The arc $X_{8}$ (exams) - $X_{9}$ (enjoyment) and the low mean value of $X_{9}$ (enjoyment) also prove the hypothesis that, students pay too much attention to vocabulary, grammar and syntax. The English teaching is geared towards teaching students to pass exams and just like a cram-and-memorize racket to some extent. Usually the student's priority is to obtain shallow recall to achieve high score, rather than to enjoy the beauty of language and rich culture of foreign countries. Students are required to memorize grammar rules and word lists in preparation for upcoming exams, especially just before they are due. For example, to pass Band Four and Six in the College English Test, students are required to memorize 4500 and 6000 words respectively. They feel boring and burdensome during learning. Among the students who disagreed that learning English was enjoyable, the percentage of students with the aim of passing the exam $(31.3 \%)$ was double the percentage of students without that goal (15.6\%). The mean value of $X_{10}$ (importance) was the second highest only after that of $X_{8}$ (exams). From arc $X_{10}$ (importance)- $X_{5}$ (relationship) in Figure 5, the emotional factor of students, i.e., $X_{10}$ (importance) was greatly affected by the relationship with friends $\left(X_{5}\right)$. Among the students who disagreed that English language learning was helpful in maintaining good relationships 
with friends, no students agreed on the importance of English. The negative feelings are transferred from behavior factors to emotional factors. The lack of communication may be the main reason why the behavioral factors and emotional factors vary greatly for L-students. The interactive teaching model may help students experience future working and studying scenarios. The English classroom needs more group work that can help students of varying English levels work together to support each other, which will benefit them greatly. This result also proves the necessity of collaborative learning and cooperative grouping for L-students.

Table 3. The CMI matrix of deciding factors to learning attitude of L-students.

\begin{tabular}{cccccccccccc}
\hline $\boldsymbol{I}\left(\boldsymbol{X}_{\boldsymbol{i}} ; \boldsymbol{X}_{\boldsymbol{j}} \mid \boldsymbol{Y}\right)$ & $\boldsymbol{X}_{\mathbf{1}}$ & $\boldsymbol{X}_{\mathbf{2}}$ & $\boldsymbol{X}_{\mathbf{4}}$ & $\boldsymbol{X}_{\mathbf{5}}$ & $\boldsymbol{X}_{\mathbf{6}}$ & $\boldsymbol{X}_{\mathbf{7}}$ & $\boldsymbol{X}_{\mathbf{8}}$ & $\boldsymbol{X}_{\mathbf{9}}$ & $\boldsymbol{X}_{\mathbf{1 0}}$ & $\boldsymbol{X}_{\mathbf{1 1}}$ & $\boldsymbol{X}_{\mathbf{1 2}}$ \\
\hline$X_{1}$ & 0.0000 & & & & & & & & & & \\
$X_{2}$ & 0.1699 & 0.0000 & & & & & & & & & \\
$X_{4}$ & 0.0528 & 0.0148 & 0.0000 & & & & & & & & \\
$X_{5}$ & 0.0493 & 0.0286 & 0.0675 & 0.0000 & & & & & & & \\
$X_{6}$ & 0.1564 & 0.0489 & 0.2595 & 0.2178 & 0.0000 & & & & & & \\
$X_{7}$ & 0.1755 & 0.0536 & 0.2224 & 0.2242 & 0.7620 & 0.0000 & & & & & \\
$X_{8}$ & 0.1199 & 0.0341 & 0.1761 & 0.1989 & 0.2807 & 0.3200 & 0.0000 & & & & \\
$X_{9}$ & 0.0622 & 0.0256 & 0.1090 & 0.3126 & 0.3641 & 0.2462 & 0.4067 & 0.0000 & & & \\
$X_{10}$ & 0.2663 & 0.0721 & 0.1959 & 0.3656 & 0.4527 & 0.4874 & 0.2907 & 0.2766 & 0.0000 & & \\
$X_{11}$ & 0.0765 & 0.0106 & 0.0082 & 0.0332 & 0.0561 & 0.0840 & 0.0683 & 0.0551 & 0.1262 & 0.0000 & \\
$X_{12}$ & 0.1298 & 0.0430 & 0.1235 & 0.0794 & 0.1529 & 0.3251 & 0.2204 & 0.2532 & 0.1681 & 0.4829 & 0.0000 \\
\hline
\end{tabular}

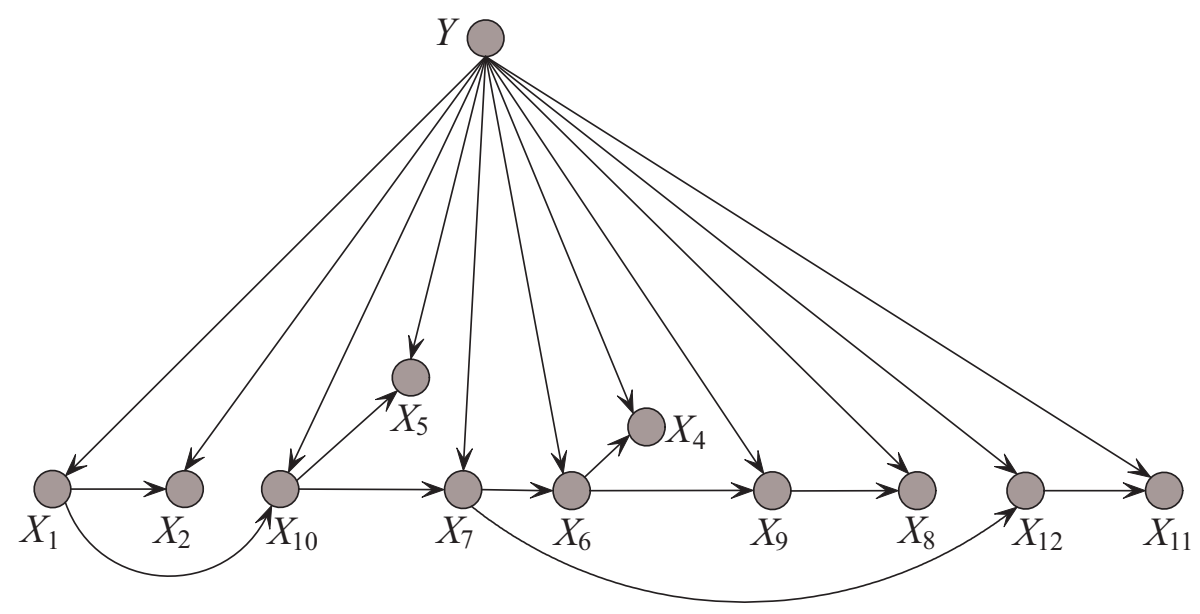

Figure 5. The topology of TAN corresponding to the CMI matrix shown in Table 3.

\subsection{Statistical Analysis for S-Students and Discussion}

By comparing the statistical results of MI and mean values in Figure 6 we can see that, for S-students $X_{12}$ (degree) achieved the highest MI and mean values. Among all the S-students, 54.8\% of them wanted to apply for a Master or PhD degree. Educational aspiration inspired students' positive attitudes toward English language learning. Emotional factors, i.e., $X_{9}$ (enjoyment) and $X_{10}$ (importance), achieved higher MI values than the cognitive factors ( $X_{6}$ (knowledge), $X_{7}$ (thoughts), $X_{8}$ (exams)), and even higher than that of behavioral factors $\left(X_{4}\right.$ (personality), $X_{5}$ (relationship)). The mean value of $X_{10}$ (importance) was the highest among internal factors except future expectation factors, 30.6\% of students recognized the importance of English and 20.9\% of students disagreed. The positive value of $X_{9}$ ( enjoyment) for S-students was 11.3 percent higher than that for L-students. Thus, as far as the emotions are concerned, more S-students agreed that studying English was enjoyable and interesting for them. Among the internal factors, the behavioral factors achieved the lowest MI values and relatively low mean values on average. Thus, for S-students, the impact of personality or interpersonal relationship on attitude toward English language learning was weak. 


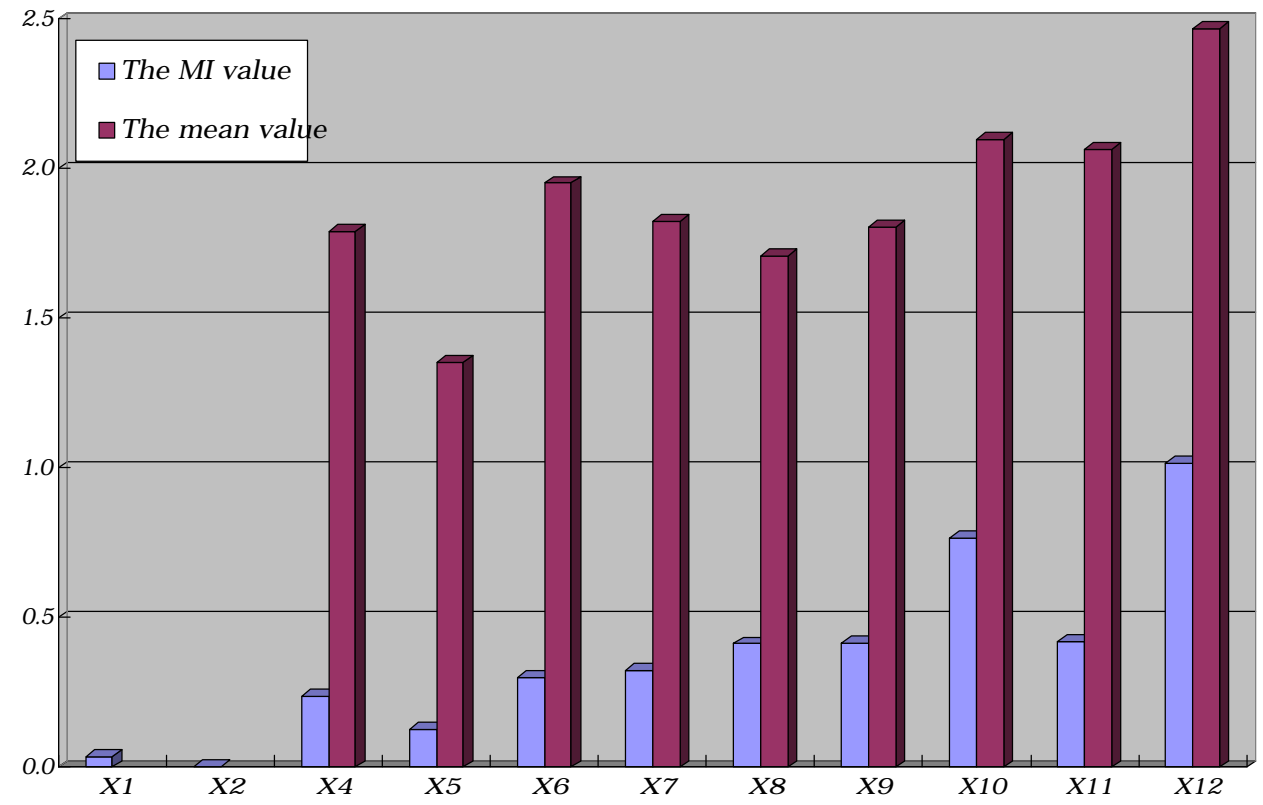

Figure 6. The MI and mean values of each deciding factor for S-students.

The CMI matrix for S-students is shown in Table 4 and the corresponding topology of TAN is shown in Figure 7.

Table 4. The CMI matrix of deciding factors to learning attitude of S-students.

\begin{tabular}{|c|c|c|c|c|c|c|c|c|c|c|c|}
\hline$I\left(X_{i} ; X_{j} \mid Y\right)$ & $X_{1}$ & $X_{2}$ & $X_{4}$ & $X_{5}$ & $X_{6}$ & $X_{7}$ & $X_{8}$ & $X_{9}$ & $X_{10}$ & $X_{11}$ & $X_{12}$ \\
\hline$X_{1}$ & 0.0000 & & & & & & & & & & \\
\hline$X_{2}$ & 0.1600 & 0.0000 & & & & & & & & & \\
\hline$X_{4}$ & 0.3512 & 0.1449 & 0.0000 & & & & & & & & \\
\hline$X_{5}$ & 0.1681 & 0.0673 & 0.2529 & 0.0000 & & & & & & & \\
\hline$X_{6}$ & 0.2921 & 0.1826 & 0.3671 & 0.1353 & 0.0000 & & & & & & \\
\hline$X_{7}$ & 0.2545 & 0.1371 & 0.2065 & 0.1495 & 0.6222 & 0.0000 & & & & & \\
\hline$X_{8}$ & 0.1271 & 0.0509 & 0.2512 & 0.1496 & 0.1843 & 0.1918 & 0.0000 & & & & \\
\hline$X_{9}$ & 0.3457 & 0.0983 & 0.3967 & 0.2043 & 0.2605 & 0.3561 & 0.3553 & 0.0000 & & & \\
\hline$X_{10}$ & 0.0859 & 0.0360 & 0.1517 & 0.1338 & 0.2635 & 0.1588 & 0.1491 & 0.2858 & 0.0000 & & \\
\hline$X_{11}$ & 0.3099 & 0.0725 & 0.2154 & 0.1394 & 0.0989 & 0.1001 & 0.2586 & 0.2172 & 0.1655 & 0.0000 & \\
\hline$X_{12}$ & 0.1257 & 0.0519 & 0.1690 & 0.0808 & 0.1179 & 0.1119 & 0.0800 & 0.1142 & 0.1819 & 0.4585 & 0.0000 \\
\hline
\end{tabular}

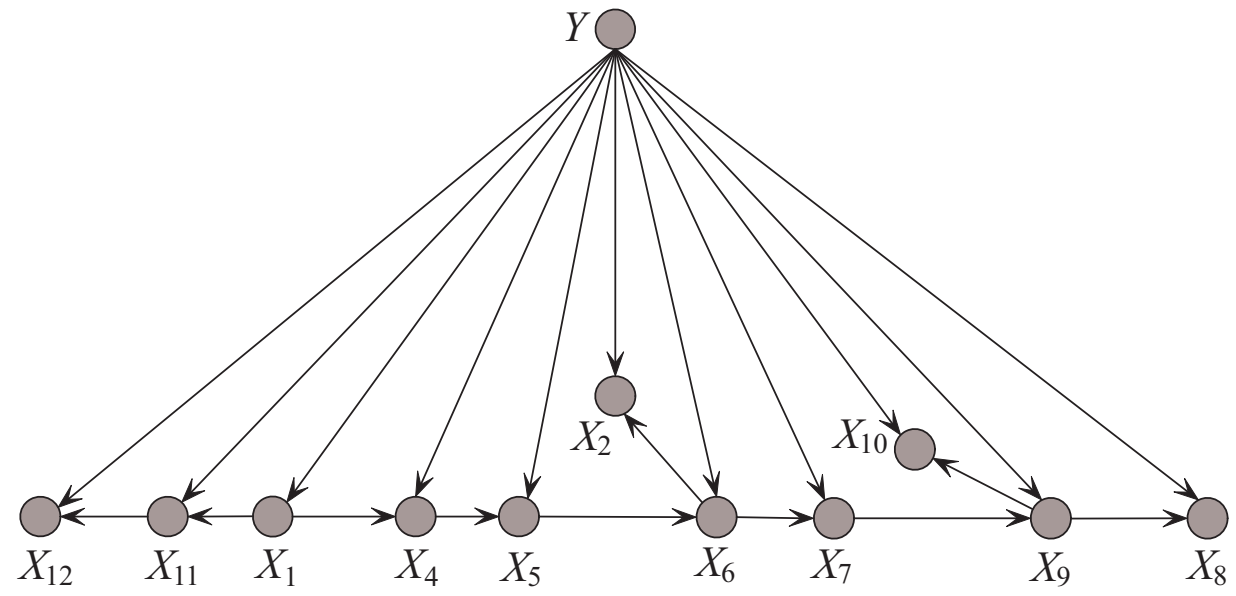

Figure 7. The topology of TAN corresponding to the CMI matrix shown in Table 4. 
From Figure 7 , arcs $X_{6}$ (knowledge)- $X_{7}$ (thoughts)- $X_{9}$ (enjoyment) demonstrate that the cognitive factors $\left(X_{6}\right.$ (knowledge), $X_{7}$ (thoughts)) affect the emotional factor $\left(X_{9}\right)$. For those S-students who agree that new thoughts and knowledge come from English language learning, about $66.7 \%$ of them feel good learning it. Considering the current English teaching scheme in China, compared to L-students, S-students are more willing to learn words, phrases, sentence and discourse. Arc $X_{8}$ (exams)- $X_{9}$ (enjoyment) demonstrate that the feeling of enjoyment affects the feelings while taking an exam. Knowledge can help students achieve a high score on the exam, and among those S-students who agreed on enjoyment during English language learning, no students took passing the exam as their target. The mean values of $X_{10}$ (importance), $X_{11}$ (corporations), $X_{12}$ (degree) for S-students were $2.0968,2.0645,2.4677$; in contrast the mean values for L-students were only 2.0313, 1.2656, 1.5625 . Obviously, S-students have stronger career or educational aspirations; thus they believe that English language learning can help them realize their future expectations, and their emotional attitudes positively reflect this. The percentage of S-students who thought that learning English was enjoyable was $19.4 \%$ higher than that of L-students. From the arcs $X_{1}-X_{11}-X_{12}, X_{1}$ (Grade) impacted future expectation factors. The percentage of S-students who had uncertain ideas about their future dropped from $72.7 \%$ in grade 1 to $50 \%$ in grade 4 , and the percentage of S-students who agreed to work or apply for a Master or PhD degree together increased from $21.3 \%$ to $35.6 \%$. That means students will have clearer future expectations as they go into higher grades. Correspondingly, their positive attitude toward English is growing stronger. For S-students, to enhance the incentive to learn English, teachers may provide videos for imitation exercises that show scenes of people attending academic conferences or conducting business affairs. Students would like to learn about their future lives.

\section{Conclusions}

Attitudes toward English language learning are influenced by many factors, including educational background, behavior, cognition, emotion, and future expectation. The interactions between these factors and the impact of these factors on attitude have been statistically analyzed in this paper. This study sets out to clarify the attitudes of undergraduate students in different majors (roughly in the Liberal Arts and Sciences) from Changchun University of Technology in China. The results of quantitative analysis of this study measured the direct and indirect impact of emotional, behavioral, and cognitive factors on attitudes toward English language learning in terms of MI, CMI and mean values. Qualitative analysis based on a Bayesian network showed the implicit interactions between these factors, and teachers can design the activities for improving learning attitude: making the learning procedure interesting and enjoyable is the key to improving learning attitude.

To deeply analyze how the factors interact and affect learning attitude, we divided the data into two groups in terms of major. The experimental results in this study corroborated the findings of Wang and Zhang (2017) that [39], the importance of English language learning is well recognized by all the participants, including both L-students and S-students. L-students' attitudes were determined by cognitive factors, whereas S-students' attitudes were determined by future expectation factors. The content of teaching materials selected by some teachers might not necessarily arouse the students' interest. L-students demonstrated negative emotional feelings when teaching materials focused on teaching of words and grammar but ignored the introduction of purpose, value and meaning. In learning a language, L-students cared more about personality development during instruction; they liked teacher-student or student-student interaction and group presentations. In contrast, S-students cared more about the number of vocabulary, collocation, phrases and the coherence of discourse that might help them achieve a high score on an English exam. Therefore, attitudes towards English language learning are affected by many factors as a fundamental component. Studying the interaction between these factors can help explain why students' attitudes toward learning vary so greatly. To arouse the learning interest and make students feel good, teachers may take different teaching approaches and employ different strategies for students in different majors. English teachers can plan specific curricula and class activities to satisfy students' needs and improve their attitudes. 
This study provides some general discussion for clarifying the attitudes of undergraduate students in Changchun University of Technology. Just some factors were considered for statistical analysis. If more factors, such as family background, are taken into consideration, the topology of TAN will correspondingly grow more complex and difficult to explain. On the other hand, this study provides a comprehensive picture of the relationships between deciding factors toward learning attitudes in terms of different majors. If the students can be further divided into subgroups according to gender or grade, we can get more interesting results and that may bring greater challenges to English teachers who must deal with this complex situation. This study highlights the value and significance of statistical analysis in English teaching and suggests that teachers should try to cultivate students' internal incentives.

Author Contributions: Conceptualization, X.Z. and L.W.; Methodology, X.Z. and L.W.; software, L.W.; Validation, X.Z. and L.W.; Formal analysis, R.W. and J.M.; investigation, R.W. and J.M.; Resources, R.W. and J.M.; Data curation, X.Z. and L.W.; Writing-original X.Z., R.W., J.M. and L.W.; Writing-review and editing, L.W.; Project administration, L.W.; Funding acquisition, X.Z.

Funding: This research was funded by the Development Project of Jilin Province (No. 20150101014JC) and Research Project of the Education Department of Jilin Province (No. JJKH20181064SK).

Conflicts of Interest: The authors declare that they have no conflict of interest.

\section{Appendix A}

Table A1. Questionnaires about English learning attitudes for L-students.

\begin{tabular}{|c|c|c|c|c|c|c|c|c|c|c|c|c|}
\hline No. & Q1 & Q2 & Q4 & Q5 & Q6 & Q7 & Q8 & Q9 & Q10 & Q11 & Q12 & Attitude \\
\hline 1 & 3 & $\mathrm{M}$ & 2 & 1 & 1 & 1 & 3 & 2 & 2 & 1 & 1 & $\mathrm{O}$ \\
\hline 2 & 3 & $\mathrm{~F}$ & 1 & 1 & 1 & 1 & 3 & 1 & 2 & 1 & 1 & $\mathrm{~N}$ \\
\hline 3 & 4 & $\mathrm{~F}$ & 1 & 1 & 1 & 1 & 3 & 1 & 2 & 1 & 1 & $\mathrm{~N}$ \\
\hline 4 & 3 & $\mathrm{M}$ & 1 & 2 & 2 & 2 & 2 & 2 & 2 & 2 & 2 & $\mathrm{~N}$ \\
\hline 5 & 2 & $\mathrm{M}$ & 2 & 1 & 2 & 2 & 3 & 1 & 2 & 1 & 2 & $\mathrm{P}$ \\
\hline 6 & 1 & $\mathrm{M}$ & 1 & 1 & 2 & 2 & 3 & 2 & 2 & 1 & 3 & $\mathrm{P}$ \\
\hline 7 & 2 & $\mathrm{M}$ & 2 & 1 & 2 & 2 & 2 & 1 & 2 & 2 & 2 & $\mathrm{O}$ \\
\hline 8 & 1 & $\mathrm{~F}$ & 2 & 1 & 3 & 3 & 2 & 1 & 2 & 1 & 2 & $\mathrm{P}$ \\
\hline 9 & 2 & $\mathrm{~F}$ & 2 & 2 & 2 & 2 & 3 & 2 & 3 & 1 & 3 & $\mathrm{P}$ \\
\hline 10 & 2 & F & 1 & 1 & 1 & 1 & 2 & 1 & 1 & 2 & 1 & $\mathrm{~N}$ \\
\hline 11 & 1 & $\mathrm{~F}$ & 2 & 1 & 2 & 2 & 2 & 1 & 2 & 1 & 3 & $\mathrm{P}$ \\
\hline 12 & 2 & $\mathrm{~F}$ & 2 & 2 & 3 & 2 & 3 & 2 & 3 & 1 & 3 & $\mathrm{P}$ \\
\hline 13 & 4 & F & 2 & 1 & 2 & 1 & 2 & 2 & 2 & 1 & 1 & $\mathrm{~N}$ \\
\hline 14 & 2 & F & 1 & 1 & 1 & 1 & 3 & 1 & 1 & 1 & 1 & $\mathrm{P}$ \\
\hline 15 & 4 & F & 1 & 1 & 1 & 1 & 3 & 1 & 2 & 1 & 1 & $\mathrm{~N}$ \\
\hline 16 & 4 & $\mathrm{~F}$ & 1 & 2 & 2 & 2 & 2 & 2 & 2 & 2 & 2 & $\mathrm{~N}$ \\
\hline 17 & 2 & F & 1 & 2 & 2 & 2 & 3 & 2 & 2 & 1 & 1 & $\mathrm{P}$ \\
\hline 18 & 2 & $\mathrm{~F}$ & 2 & 1 & 2 & 2 & 2 & 1 & 3 & 1 & 1 & $\mathrm{P}$ \\
\hline 19 & 3 & $\mathrm{~F}$ & 2 & 2 & 2 & 2 & 3 & 3 & 3 & 1 & 1 & $\mathrm{O}$ \\
\hline 20 & 3 & $\mathrm{M}$ & 1 & 1 & 1 & 1 & 2 & 1 & 2 & 1 & 1 & $\mathrm{~N}$ \\
\hline 21 & 3 & $\mathrm{M}$ & 2 & 1 & 2 & 2 & 2 & 1 & 2 & 1 & 1 & $\mathrm{~N}$ \\
\hline 22 & 3 & $\mathrm{~F}$ & 2 & 2 & 3 & 3 & 3 & 2 & 3 & 1 & 3 & $\mathrm{O}$ \\
\hline 23 & 3 & $\mathrm{~F}$ & 2 & 1 & 2 & 2 & 3 & 2 & 1 & 2 & 2 & $\mathrm{~N}$ \\
\hline 24 & 3 & $\mathrm{M}$ & 1 & 1 & 1 & 1 & 3 & 1 & 2 & 2 & 2 & $\mathrm{~N}$ \\
\hline 25 & 3 & $\mathrm{~F}$ & 1 & 1 & 1 & 1 & 3 & 1 & 2 & 1 & 1 & $\mathrm{~N}$ \\
\hline 26 & 4 & F & 1 & 2 & 2 & 2 & 2 & 1 & 2 & 1 & 1 & $\mathrm{~N}$ \\
\hline 27 & 2 & $\mathrm{~F}$ & 2 & 1 & 2 & 2 & 2 & 1 & 2 & 1 & 1 & $\mathrm{O}$ \\
\hline 28 & 4 & F & 2 & 1 & 2 & 2 & 2 & 2 & 2 & 1 & 3 & $\mathrm{~N}$ \\
\hline 29 & 4 & $\mathrm{~F}$ & 2 & 1 & 2 & 2 & 2 & 1 & 2 & 1 & 1 & $\mathrm{O}$ \\
\hline 30 & 2 & F & 2 & 1 & 2 & 2 & 2 & 1 & 2 & 2 & 2 & $\mathrm{P}$ \\
\hline 31 & 2 & $\mathrm{~F}$ & 2 & 2 & 2 & 2 & 1 & 2 & 3 & 2 & 2 & $\mathrm{P}$ \\
\hline 32 & 3 & $\mathrm{~F}$ & 1 & 1 & 1 & 1 & 2 & 1 & 1 & 2 & 1 & $\mathrm{~N}$ \\
\hline 33 & 3 & $\mathrm{M}$ & 2 & 1 & 2 & 2 & 2 & 1 & 2 & 1 & 1 & $\mathrm{P}$ \\
\hline 34 & 3 & $\mathrm{M}$ & 2 & 2 & 2 & 3 & 1 & 2 & 3 & 1 & 3 & $\mathrm{~N}$ \\
\hline 35 & 3 & $\mathrm{~F}$ & 1 & 1 & 1 & 1 & 2 & 1 & 1 & 1 & 1 & $\mathrm{~N}$ \\
\hline
\end{tabular}


Table A1. Cont.

\begin{tabular}{ccccccccccccc}
\hline No. & Q1 & Q2 & Q4 & Q5 & Q6 & Q7 & Q8 & Q9 & Q10 & Q11 & Q12 & Attitude \\
\hline 36 & 3 & $\mathrm{~F}$ & 2 & 1 & 2 & 2 & 2 & 1 & 2 & 1 & 1 & $\mathrm{~N}$ \\
37 & 3 & $\mathrm{M}$ & 1 & 2 & 3 & 2 & 1 & 2 & 3 & 1 & 1 & $\mathrm{O}$ \\
38 & 3 & $\mathrm{~F}$ & 2 & 1 & 2 & 2 & 1 & 2 & 2 & 2 & 2 & $\mathrm{~N}$ \\
39 & 2 & $\mathrm{~F}$ & 1 & 1 & 1 & 1 & 3 & 1 & 1 & 2 & 2 & $\mathrm{~N}$ \\
40 & 3 & $\mathrm{~F}$ & 2 & 1 & 1 & 1 & 3 & 1 & 2 & 1 & 1 & $\mathrm{~N}$ \\
41 & 2 & $\mathrm{M}$ & 1 & 2 & 2 & 2 & 2 & 2 & 2 & 1 & 1 & $\mathrm{O}$ \\
42 & 3 & $\mathrm{M}$ & 2 & 1 & 2 & 2 & 1 & 1 & 2 & 1 & 1 & $\mathrm{O}$ \\
43 & 2 & $\mathrm{~F}$ & 1 & 1 & 2 & 2 & 1 & 2 & 2 & 1 & 1 & $\mathrm{P}$ \\
44 & 3 & $\mathrm{M}$ & 2 & 1 & 2 & 2 & 2 & 1 & 2 & 1 & 3 & $\mathrm{O}$ \\
45 & 2 & $\mathrm{~F}$ & 1 & 2 & 2 & 2 & 2 & 1 & 2 & 1 & 1 & $\mathrm{O}$ \\
46 & 3 & $\mathrm{M}$ & 2 & 1 & 2 & 2 & 2 & 1 & 2 & 1 & 1 & $\mathrm{O}$ \\
47 & 2 & $\mathrm{~F}$ & 2 & 1 & 2 & 2 & 2 & 2 & 2 & 1 & 3 & $\mathrm{P}$ \\
48 & 4 & $\mathrm{~F}$ & 2 & 1 & 2 & 2 & 2 & 1 & 2 & 1 & 1 & $\mathrm{~N}$ \\
49 & 4 & $\mathrm{~F}$ & 2 & 1 & 2 & 2 & 2 & 1 & 2 & 2 & 2 & $\mathrm{~N}$ \\
50 & 2 & $\mathrm{M}$ & 2 & 2 & 2 & 2 & 1 & 2 & 3 & 2 & 2 & $\mathrm{P}$ \\
51 & 3 & $\mathrm{~F}$ & 1 & 1 & 1 & 1 & 2 & 1 & 1 & 2 & 1 & $\mathrm{O}$ \\
52 & 2 & $\mathrm{~F}$ & 2 & 1 & 2 & 2 & 2 & 1 & 2 & 1 & 1 & $\mathrm{P}$ \\
53 & 3 & $\mathrm{~F}$ & 2 & 2 & 2 & 3 & 1 & 2 & 3 & 1 & 3 & $\mathrm{~N}$ \\
54 & 2 & $\mathrm{M}$ & 1 & 1 & 1 & 1 & 2 & 1 & 1 & 1 & 1 & $\mathrm{P}$ \\
55 & 3 & $\mathrm{M}$ & 2 & 1 & 2 & 2 & 2 & 1 & 2 & 1 & 1 & $\mathrm{O}$ \\
56 & 2 & $\mathrm{~F}$ & 1 & 2 & 3 & 2 & 1 & 2 & 3 & 1 & 1 & $\mathrm{P}$ \\
57 & 3 & $\mathrm{M}$ & 2 & 1 & 2 & 2 & 1 & 2 & 2 & 2 & 2 & $\mathrm{~N}$ \\
58 & 2 & $\mathrm{~F}$ & 2 & 1 & 2 & 2 & 1 & 1 & 2 & 1 & 1 & $\mathrm{O}$ \\
59 & 3 & $\mathrm{M}$ & 1 & 1 & 1 & 1 & 2 & 1 & 1 & 1 & 1 & $\mathrm{~N}$ \\
60 & 2 & $\mathrm{~F}$ & 2 & 1 & 2 & 2 & 2 & 1 & 2 & 1 & 1 & $\mathrm{P}$ \\
61 & 4 & $\mathrm{~F}$ & 1 & 2 & 3 & 2 & 1 & 2 & 3 & 1 & 1 & $\mathrm{O}$ \\
62 & 4 & $\mathrm{~F}$ & 2 & 1 & 2 & 2 & 1 & 2 & 2 & 2 & 2 & $\mathrm{~N}$ \\
63 & 2 & $\mathrm{M}$ & 1 & 1 & 1 & 1 & 3 & 1 & 1 & 2 & 2 & $\mathrm{P}$ \\
64 & 3 & $\mathrm{~F}$ & 2 & 1 & 1 & 1 & 3 & 1 & 2 & 1 & 1 & $\mathrm{~N}$ \\
\hline
\end{tabular}

Table A2. Questionnaires about English learning attitudes for S-students.

\begin{tabular}{ccccccccccccc}
\hline No. & Q1 & Q2 & Q4 & Q5 & Q6 & Q7 & Q8 & Q9 & Q10 & Q11 & Q12 & Attitude \\
\hline 1 & 1 & M & 2 & 1 & 3 & 2 & 1 & 1 & 1 & 3 & 3 & $\mathrm{~N}$ \\
2 & 1 & M & 1 & 1 & 1 & 1 & 3 & 1 & 1 & 3 & 3 & $\mathrm{~N}$ \\
3 & 1 & $\mathrm{~F}$ & 2 & 1 & 2 & 1 & 2 & 1 & 2 & 3 & 3 & $\mathrm{~N}$ \\
4 & 3 & $\mathrm{~F}$ & 3 & 2 & 2 & 2 & 1 & 3 & 3 & 3 & 1 & $\mathrm{O}$ \\
5 & 1 & $\mathrm{~F}$ & 2 & 1 & 3 & 3 & 1 & 3 & 3 & 1 & 3 & $\mathrm{P}$ \\
6 & 2 & $\mathrm{M}$ & 2 & 2 & 2 & 1 & 1 & 2 & 3 & 1 & 3 & $\mathrm{P}$ \\
7 & 1 & $\mathrm{M}$ & 1 & 1 & 1 & 1 & 2 & 1 & 1 & 3 & 2 & $\mathrm{~N}$ \\
8 & 1 & $\mathrm{~F}$ & 2 & 1 & 2 & 2 & 2 & 1 & 2 & 1 & 3 & $\mathrm{P}$ \\
9 & 4 & $\mathrm{~F}$ & 3 & 2 & 3 & 3 & 1 & 3 & 3 & 1 & 3 & $\mathrm{P}$ \\
10 & 1 & $\mathrm{~F}$ & 2 & 1 & 2 & 2 & 1 & 2 & 1 & 3 & 3 & $\mathrm{~N}$ \\
11 & 3 & $\mathrm{~F}$ & 1 & 1 & 1 & 1 & 3 & 1 & 1 & 3 & 3 & $\mathrm{~N}$ \\
12 & 1 & $\mathrm{~F}$ & 1 & 1 & 2 & 2 & 2 & 2 & 2 & 2 & 2 & $\mathrm{O}$ \\
13 & 5 & $\mathrm{M}$ & 2 & 1 & 2 & 2 & 1 & 2 & 2 & 2 & 2 & $\mathrm{O}$ \\
14 & 4 & $\mathrm{~F}$ & 2 & 2 & 2 & 2 & 2 & 2 & 2 & 2 & 2 & $\mathrm{O}$ \\
15 & 1 & $\mathrm{M}$ & 1 & 1 & 1 & 1 & 2 & 2 & 2 & 2 & 2 & $\mathrm{O}$ \\
16 & 2 & $\mathrm{M}$ & 2 & 1 & 1 & 1 & 2 & 2 & 2 & 1 & 3 & $\mathrm{O}$ \\
17 & 1 & $\mathrm{~F}$ & 1 & 1 & 3 & 2 & 1 & 2 & 3 & 3 & 1 & $\mathrm{O}$ \\
18 & 3 & $\mathrm{M}$ & 2 & 1 & 2 & 2 & 1 & 1 & 3 & 3 & 1 & $\mathrm{P}$ \\
19 & 4 & $\mathrm{~F}$ & 3 & 2 & 2 & 2 & 1 & 3 & 3 & 1 & 3 & $\mathrm{P}$ \\
20 & 1 & $\mathrm{~F}$ & 1 & 2 & 2 & 2 & 2 & 2 & 2 & 2 & 2 & $\mathrm{O}$ \\
21 & 2 & $\mathrm{M}$ & 2 & 1 & 3 & 3 & 2 & 3 & 3 & 2 & 2 & $\mathrm{O}$ \\
22 & 1 & $\mathrm{~F}$ & 1 & 1 & 3 & 3 & 1 & 3 & 3 & 1 & 3 & $\mathrm{P}$ \\
\hline
\end{tabular}


Table A2. Cont.

\begin{tabular}{|c|c|c|c|c|c|c|c|c|c|c|c|c|}
\hline No. & Q1 & Q2 & Q4 & Q5 & Q6 & Q7 & Q8 & Q9 & Q10 & Q11 & Q12 & Attitude \\
\hline 23 & 4 & $\mathrm{M}$ & 2 & 2 & 2 & 2 & 2 & 2 & 2 & 2 & 2 & $\mathrm{O}$ \\
\hline 24 & 1 & $\mathrm{~F}$ & 2 & 2 & 2 & 2 & 2 & 2 & 2 & 2 & 2 & $\mathrm{O}$ \\
\hline 25 & 4 & $\mathrm{M}$ & 2 & 1 & 2 & 1 & 1 & 1 & 2 & 2 & 2 & $\mathrm{O}$ \\
\hline 26 & 2 & $\mathrm{~F}$ & 2 & 1 & 2 & 2 & 1 & 1 & 2 & 2 & 3 & $\mathrm{O}$ \\
\hline 27 & 3 & $\mathrm{~F}$ & 3 & 2 & 2 & 2 & 1 & 3 & 3 & 1 & 3 & P \\
\hline 28 & 1 & $\mathrm{~F}$ & 1 & 2 & 2 & 2 & 2 & 2 & 2 & 2 & 2 & $\mathrm{O}$ \\
\hline 29 & 4 & $\mathrm{M}$ & 2 & 1 & 2 & 2 & 1 & 2 & 2 & 2 & 2 & $\mathrm{O}$ \\
\hline 30 & 1 & $\mathrm{~F}$ & 2 & 2 & 2 & 2 & 2 & 2 & 2 & 2 & 2 & $\mathrm{O}$ \\
\hline 31 & 2 & $\mathrm{M}$ & 2 & 1 & 1 & 1 & 2 & 2 & 2 & 1 & 3 & P \\
\hline 32 & 2 & $\mathrm{~F}$ & 1 & 1 & 3 & 2 & 1 & 2 & 3 & 3 & 1 & P \\
\hline 33 & 1 & $\mathrm{~F}$ & 1 & 1 & 3 & 3 & 1 & 3 & 3 & 1 & 3 & P \\
\hline 34 & 3 & $\mathrm{M}$ & 2 & 2 & 2 & 2 & 2 & 2 & 2 & 2 & 2 & $\mathrm{O}$ \\
\hline 35 & 1 & $\mathrm{~F}$ & 2 & 2 & 2 & 2 & 2 & 2 & 2 & 2 & 2 & $\mathrm{O}$ \\
\hline 36 & 4 & $\mathrm{M}$ & 1 & 1 & 1 & 1 & 3 & 1 & 1 & 3 & 3 & $\mathrm{~N}$ \\
\hline 37 & 3 & $\mathrm{~F}$ & 1 & 1 & 1 & 1 & 3 & 1 & 2 & 3 & 3 & $\mathrm{~N}$ \\
\hline 38 & 3 & $\mathrm{~F}$ & 2 & 1 & 2 & 1 & 3 & 1 & 1 & 3 & 3 & $\mathrm{~N}$ \\
\hline 39 & 1 & $\mathrm{M}$ & 1 & 1 & 1 & 1 & 3 & 1 & 2 & 3 & 3 & $\mathrm{~N}$ \\
\hline 40 & 3 & $\mathrm{~F}$ & 2 & 2 & 2 & 2 & 2 & 1 & 2 & 3 & 3 & $\mathrm{~N}$ \\
\hline 41 & 2 & $\mathrm{~F}$ & 2 & 1 & 2 & 2 & 1 & 2 & 2 & 2 & 1 & $\mathrm{P}$ \\
\hline 42 & 4 & $\mathrm{M}$ & 2 & 2 & 2 & 2 & 2 & 2 & 2 & 2 & 2 & $\mathrm{O}$ \\
\hline 43 & 2 & $\mathrm{M}$ & 1 & 1 & 1 & 1 & 3 & 1 & 1 & 3 & 3 & $\mathrm{~N}$ \\
\hline 44 & 2 & $\mathrm{~F}$ & 1 & 2 & 2 & 2 & 2 & 2 & 2 & 2 & 2 & $\mathrm{O}$ \\
\hline 45 & 2 & $\mathrm{~F}$ & 2 & 1 & 3 & 3 & 2 & 3 & 3 & 2 & 2 & $\mathrm{O}$ \\
\hline 46 & 3 & $\mathrm{~F}$ & 2 & 1 & 2 & 1 & 1 & 1 & 2 & 2 & 2 & $\mathrm{O}$ \\
\hline 47 & 2 & $\mathrm{M}$ & 2 & 1 & 2 & 2 & 1 & 1 & 2 & 2 & 3 & $\mathrm{O}$ \\
\hline 48 & 3 & $\mathrm{M}$ & 3 & 2 & 2 & 2 & 1 & 3 & 3 & 1 & 3 & $P$ \\
\hline 49 & 2 & $\mathrm{~F}$ & 1 & 1 & 1 & 1 & 2 & 1 & 1 & 3 & 2 & $\mathrm{~N}$ \\
\hline 50 & 3 & $\mathrm{M}$ & 2 & 1 & 2 & 2 & 2 & 1 & 2 & 1 & 3 & $P$ \\
\hline 51 & 2 & $\mathrm{~F}$ & 3 & 2 & 3 & 3 & 1 & 3 & 3 & 1 & 3 & P \\
\hline 52 & 3 & $\mathrm{M}$ & 2 & 1 & 2 & 2 & 1 & 2 & 1 & 3 & 3 & $\mathrm{~N}$ \\
\hline 53 & 2 & $\mathrm{~F}$ & 1 & 1 & 1 & 1 & 3 & 1 & 1 & 3 & 3 & $\mathrm{~N}$ \\
\hline 54 & 4 & $\mathrm{~F}$ & 1 & 1 & 1 & 1 & 3 & 1 & 1 & 3 & 3 & $\mathrm{~N}$ \\
\hline 55 & 4 & $\mathrm{~F}$ & 1 & 2 & 2 & 2 & 2 & 2 & 2 & 2 & 2 & $\mathrm{O}$ \\
\hline 56 & 2 & $\mathrm{M}$ & 2 & 1 & 2 & 2 & 1 & 1 & 2 & 2 & 3 & $\mathrm{O}$ \\
\hline 57 & 3 & $\mathrm{~F}$ & 3 & 2 & 2 & 2 & 1 & 3 & 3 & 1 & 3 & $\mathrm{P}$ \\
\hline 58 & 2 & $\mathrm{M}$ & 2 & 1 & 2 & 2 & 1 & 1 & 3 & 1 & 3 & $\mathrm{P}$ \\
\hline 59 & 4 & $\mathrm{~F}$ & 3 & 2 & 2 & 2 & 1 & 3 & 3 & 1 & 3 & P \\
\hline 60 & 2 & $\mathrm{~F}$ & 1 & 1 & 1 & 1 & 2 & 1 & 1 & 3 & 2 & $\mathrm{~N}$ \\
\hline 61 & 4 & $\mathrm{M}$ & 2 & 1 & 2 & 2 & 2 & 1 & 2 & 2 & 2 & $P$ \\
\hline 62 & 2 & $\mathrm{~F}$ & 2 & 2 & 3 & 3 & 2 & 2 & 3 & 1 & 3 & $\mathrm{P}$ \\
\hline
\end{tabular}

\section{References}

1. Most Chinese Kids Learn English Just for Entrance Exams. Available online: http:/ /www.chinadaily.com. cn/beijing/2013-11/14/content_17112871.htm (accessed on 24 April 2019).

2. Abdullah, S. Encouraging Students to Have Positive Attitudes toward Learning English. Ethical Ling. J. Lang. Teach. Lit. 2016, 3, 122-130. [CrossRef]

3. Agustina, L. Enhancing the Students' Positive Attitude in Learning Business English by Using Technology. Adv. Lang. Lit. Stud. 2017, 8, 51-57. [CrossRef]

4. Gardner, R.C.; Lambert, W.E. Motivational variables in second-language acquisition. Can. J. Psychol./Revue Canadienne de Psychologie 1959, 13, 266-272. [CrossRef]

5. Tan, P.J.B. English e-learning in the virtual classroom and the factors that influence ESL (English as a second language): Taiwanese citizens' acceptance and use of the modular object-oriented dynamic learning environment. Soc. Sci. Inf. 2015, 54, 221-228. [CrossRef]

6. Tan, P.J.B. Applying the UTAUT to Understand Factors Affecting the Use of English E-Learning Websites in Taiwan. SAGE Open 2013, 3, 1-12. [CrossRef] 
7. Tan, P.J.B.; Hsu, M.H. Designing a System for English Evaluation and Teaching Devices: A PZB and TAM Model Analysis. EURASIA J. Math. Sci. Technol. Educ. 2018, 14, 2107-2119. [CrossRef]

8. Tan, P.J.B.; Hsu, M.H. Developing a system for English evaluation and teaching devices. In Proceedings of the 2017 International Conference on Applied System Innovation (ICASI), Sapporo, Japan, 13-17 May 2017; pp. 938-941. [CrossRef]

9. Tan, P.J.B. An Empirical Study of How the Learning Attitudes of College Students toward English E-Tutoring Websites Affect Site Sustainability. Sustainability 2019, 11, 1748. [CrossRef]

10. Tan, P.J.B.; Hsu, M.H. Management of Educational Needs of Employees in the Electronics Industry Using English e-Learning Website Programs. In Management of Information Systems; Intech Open: London, UK, 2018; pp. 203-221.

11. Sebastian, M.; Rafael, A.; Rocío, A. Social media-based collaborative learning: Exploring antecedents of attitude. Internet High. Educ. 2018, 38, 18-27. [CrossRef]

12. Magen-Nagar, N.; Shonfeld, M. The impact of an online collaborative learning program on students' attitude towards technology. Interact. Learn. Environ. 2018, 26, 621-637. [CrossRef]

13. Mikami, A. Students' Attitudes toward Extensive Reading in the Japanese EFL Context. TESOL J. 2017, 8 , 471-488. [CrossRef]

14. Ximena, A.C.S.; Lorena, F.P.G. Learners' attitudes toward extensive reading in EFL (English as a Foreign Language) contexts. Publicando 2017, 4, 471-488.

15. Jabali, O. Students' attitudes towards EFL university writing: A case study at An-Najah National University, Palestine. Sociology 2018, 4, e00896. [CrossRef]

16. Alzaidiyeen, N.J. English as a Foreign Language Students Attitudes towards the Utilization of iPad in Language Learning. Malays. Online J. Educ. Technol. 2017, 5, 16-24.

17. Kamariah, A.B.; Rohani, A.T.; Rahil, M.; Ahmad, F.M. Relationships between university students' achievement motivation, attitude and academic performance in Malaysia. Soc. Behav. Sci. 2010, 2, 4906-4910. [CrossRef]

18. Lateef, A. Influence of Achievement Motivation on Nigerian Undergraduates' Attitude towards Examination. Int. J. Instr. 2018, 11, 77-88. [CrossRef]

19. Brown, H.D. Principles of Language Learning and Teaching; Prentice Hall: Englewood Cliffs, NJ, USA, 1994.

20. Pienemann, M.; Johnston, M. Factors influencing the development of language proficiency. In Applying Second Language Acquisition Research; Nunan, D., Ed.; NCRC Research Series: Adelaide, Australia, 1987.

21. Spolsky, B. Conditions for Second Language Learning; Oxford University Press: Oxford, UK, 1989.

22. Shahrzad, E.; Kris, G. EFL students' attitudes toward learning English language: The case study of Kashan University students. Cogent Educ. 2016, 3, 1236434. [CrossRef]

23. Kara, A. The effect of a 'learning theories' unit on students' attitudes towards learning. Aust. J. Teach. Educ. 2009, 34, 100-113. [CrossRef]

24. Yasuhiro, I. Emotions in SLA: New Insights From Collaborative Learning for an EFL Classroom. Mod. Lang. J. 2010, 94, 278-292. [CrossRef]

25. Yu, L. A study of english reading ability based on multiple linear regression analysis. J. Chem. Pharm. Res. 2014, 6, 1870-1877.

26. Katalin, V.G.; Attila, M.; József, V. Regression Analysis of Influencing Factors of Public Education in Hungary. Acta Univ. Sapientiae Econ. Bus. 2016, 4, 67-84.

27. Kalet, A.; Doctor, J.; Gennari, J.; Phillips, M. Developing Bayesian networks from a dependency-layered ontology: A proof-of-concept in radiation oncology. Med. Phys. 2017, 44, 4350-4359. [CrossRef]

28. Luo, Y.; McShan, D.; Matuszak, M.; Ray, D.; Lawrence, T.S.; Jolly, S.; Kong, F.M.; Ten Haken, R.K.; El Naqa, I. A multiobjective Bayesian networks approach for joint prediction of tumor local control and radiation pneumonitis in nonsmall-cell lung cancer (NSCLC) for response-adapted radiotherapy. Med. Phys. 2018, 45, 3980-3995. [CrossRef] [PubMed]

29. Durante, D.; Paganin, S.; Scarpa, B.; Dunson, D.B. Bayesian modelling of networks in complex business intelligence problems. J. R. Stat. Soc. Ser. C Appl. Stat. 2017, 66, 555-580. [CrossRef]

30. Bulut, K.; Kayakutlu, G.; Daim, T. Tri-generation investment analysis using Bayesian network: A case study. Int. J. Green Energy 2018, 15, 347-357. [CrossRef] 
31. Belland, B.R.; Walker, A.E.; Kim, N.J. A Bayesian Network Meta-Analysis to Synthesize the Influence of Contexts of Scaffolding Use on Cognitive Outcomes in STEM Education. Rev. Educ. Res. 2017, 87, 1042-1081. [CrossRef] [PubMed]

32. Lacave, C.; Molina, A.I. Using Bayesian Networks for Learning Analytics in Engineering Education: A Case Study on Computer Science Dropout at UCLM. Int. J. Eng. Educ. 2018, 34, 879-894.

33. Friedman, N.; Geiger, D.; Goldszmidt, M. Bayesian network classifiers. Mach. Learn. 1997, 29, $131-163$. [CrossRef]

34. Chow, C.K.; Liu, C.N. Approximating discrete probability distributions with dependence trees. IEEE Trans. Inf. Theory 1968, 14, 462-467. [CrossRef]

35. Kruskal, J.B. On the Shortest Spanning Subtree of a Graph and the Traveling Salesman Problem. Proc. Am. Math. Soc. 1956, 7, 48-50. [CrossRef]

36. Shannon, C.E. The Mathematical Theory of Communication; University of Illinois Press: Champaign, IL, USA, 1949.

37. Gaibani, A.; Elmenfi, F. Age as an Affective Factor in Influencing Public Speaking Anxiety of English Language Learners at Omar Al-Mukhtar University. Adv. Lang. Lit. Stud. 2016, 7, 179-182. [CrossRef]

38. Schaller-Schwaner, I. The Habitat Factor in ELF(A)-English as a Lingua Franca (In Academic Settings)-And English for Plurilingual Academic Purposes. Lang. Learn. High. Educ. 2015, 5, 329-351. [CrossRef]

39. Wang, S.; Zhang, Y. Study of Writing Problem in College General English Course-Reflection on the Reform of College English Course. J. Lang. Teach. Res. 2017, 8, 176-183. [CrossRef]

(C) 2019 by the authors. Licensee MDPI, Basel, Switzerland. This article is an open access article distributed under the terms and conditions of the Creative Commons Attribution (CC BY) license (http:/ / creativecommons.org/licenses/by/4.0/). 